\title{
Microbial Profile and Antimicrobial Effect of Donkey Milk against Staphylococcus aureus
}

\author{
K.M. Chandrashekar ${ }^{1 *}$, R. Sharada ${ }^{1}$ and S. Isloor ${ }^{2}$ \\ ${ }^{1}$ Department of Veterinary Microbiology, Veterinary College, Hassan - 573 202, KVAFSU, \\ Karnataka, India \\ ${ }^{2}$ Department of Veterinary Microbiology, Veterinary College, Bangalore - 560024 , \\ KVAFSU, Karnataka, India \\ *Corresponding author
}

\section{Keywords}

Donkey milk,

Microbial profile,

Antimicrobial

effect, Lysozyme

Article Info

Accepted:

26 February 2018

Available Online:

10 March 2018

\section{A B S T R A C T}

In India, there is a growing interest in donkey milk mainly because of its antimicrobial properties. The aim of this study was to know the microbial profile and to investigate antibacterial effect of raw donkey milk against Staphylococcus aureus (S. aureus). Average values of fat, SNF, cholesterol, proteins, lactose, salt, temperature and $\mathrm{pH}$ were $0.67,8.05,30.4,2.95,4.43$, $0.66,30.83{ }^{\circ} \mathrm{C}$ and 7.08 respectively. The total viable count in the neat donkey milk samples varied from 220 to $2080 \mathrm{cfu} / \mathrm{ml}$ (918 or $2.96 \mathrm{log}$ $\mathrm{cfu} / \mathrm{ml}$ on average). All samples were negative for moulds/yeast and also for pathogenic bacteria like S. aureus, Salmonella spp., E. coli, Bacillus cereus and Streptococcus spp. In two samples, the bacterial count reduced below the detection limit of $<1 \mathrm{log} \mathrm{cfu} / \mathrm{ml}$ after $5 \mathrm{hr}$ of incubation which indicates the antimicrobial effects of donkey milk. In disc diffusion test a clear zone of inhibition was noticed.

\section{Introduction}

In India, donkey milk (DM) is gaining lot of attention for human (children) consumption in view of its medicinal and therapeutic values with special reference to its antimicrobial property. Since ages, donkey milk has been known for its significant medicinal and therapeutic properties (Zhang et al., 2008, Vincenzetti et al., 2008). Some of these properties of DM are in prevention of atherosclerosis (Tafaro et al., 2007), antibacterial (Saric et al., 2012; Tidona et al., 2011; Zhang et al., 2008) antiviral (Brumini et al., 2013), antiproliferative and anti-tumor effects (Mao et al., 2009) but majority of its application is by considering it as a alternative to cow/mother milk for children affected with milk allergy. The DM is having higher tolerability, palatability, nutritional adequacy (Iacono et al., 1992; Mansueto et al., 2013; Monti et al., 2007, 2012) Low fat and casein 
content, high percentage of lactose, lysozymes and essential amino acids (Vincenzetti et al., 2008). The objective of this study was to know the microbial profile and to investigate antibacterial effect of raw DM against Staphylococcus aureus (S. aureus).

\section{Materials and Methods}

\section{Sample collection}

Fresh donkey milk samples were collected from eight apparently healthy donkeys in their third month of lactation. Initially, the udder was cleaned with water and then dried with cloth \& then the animals were milked. Immediately after collection, the milk was transported to laboratory and $\mathrm{pH}$ of the milk was recorded.

\section{Milk chemical and biochemical analyses}

Ten milliliter of DM from each sample was subjected into sensor based milk analyzer (Ksheeraa - by Dairy equipments limited, India) to know the chemical and biochemical analyses like FAT, SNF (Solid not fat), CLR (Cholesterol), Water, Temperature, PTN (Protein), LCT (Lactose) and SLT (Salt).

\section{Microbial profile}

To asses total bacterial or viable count, serial log dilution of milk samples was conducted in sterile saline $(1 \mathrm{ml}$ milk $+9 \mathrm{ml}$ saline $)$ and $100 \mu \mathrm{l}$ of Neat (undiluted), $10^{-1}, 10^{-2}$ dilutions were spread on PCA (Plate count agar) in duplicate by L spreaders (Himedia) to assess total bacterial or viable count and plates are incubated at $37{ }^{\circ} \mathrm{C}$ for overnight. The results were then expressed as $\mathrm{cfu} / \mathrm{mL}$.

Neat milk samples $(100 \mu l)$ in duplicate were spread on SDA (Sabarouds dextrose agar), MSA (Mannitol salt agar), MCA (McConkey agar), XLD (Xylose lysine deoxycholate),
BCA (Bacillus cereus agar), Deoxy Lactose agar and Edwards medium to identify the pathogenic moulds/yeast, $S$. aureus, Lactose fermenters/Lactose non-fermenters, Salmonella, Bacillus cereus, Coliforms and Streptococcus, respectively and incubated overnight at $37^{\circ} \mathrm{C}$.

\section{Antibacterial assay}

The antibacterial assay was performed on milk samples using $S$. aureus reference strain (MTCC No. 96) (Accession No. JN247783). After overnight incubation on BHI at $37{ }^{\circ} \mathrm{C}$, well-isolated colony of $S$. aureus was selected and transferred with an inoculating loop to a tube of sterile saline and vortexed thoroughly. The density of the bacterial suspension was adjusted to $0.5 \mathrm{McFarland}\left(1.5 \times 10^{8} \mathrm{cfu} / \mathrm{ml}\right)$ using McFarland standards (Himedia, India). Further decimal dilutions ( $1 \mathrm{ml}$ of bacterial suspension $+9 \mathrm{ml}$ of saline) to get $10^{7}$ cfus, $10^{6}$ cfus, $10^{5}$ cfus, $10^{4}$ and $10^{3}$ cfus in sterile saline were prepared from initial suspensions.

The DM samples $(9 \mathrm{ml})$ were spiked to mimic the contamination with the bacterial suspension $(1 \mathrm{ml})$ at the level of contamination of $10^{3} \mathrm{cfu} / \mathrm{mL}$.

$10 \mathrm{~mL}$ of each artificially contaminated sample were placed into a sterile beaker and kept in water bath at $38 \pm 0.5{ }^{\circ} \mathrm{C}$ for 5 hours duration. Changes in the number of tested bacteria were monitored at every one \& five hour by spreading $200 \mu \mathrm{l}$ on MSA or on BHI agar in duplicate. Non inoculated DM was used as negative control, while artificially contaminated nutrient broth (Himedia, India) was used as positive control. Further circular Whattman filter paper were suspended in neat, $10^{-1}$ and $10^{-2}$ diluted milk samples and these dried discs were placed on the MHA plate streaked with 0.5 Mcfarland $S$. aureus bacterial suspension, incubated overnight (Disc diffusion test). 


\section{Results and Discussion}

All samples on an average showed a $\mathrm{pH}$ of $7.08 \&$ temperature of $30.83{ }^{\circ} \mathrm{C}$. The average values of fat, SNF, cholesterol, proteins, lactose \& salt were $0.67,8.05,30.4,2.95,4.43$ and 0.66 , respectively. The total viable count in the neat donkey milk samples varied from $220-2080 \mathrm{cfu} / \mathrm{ml}$ (918 or $2.96 \mathrm{log} \mathrm{cfu} / \mathrm{ml}$ on average). The mesophilic total viable bacterial count in our study was in agreement with Pilla et al., 2010 (1 to $2.39 \log \mathrm{cfu} / \mathrm{ml}$ ) and in contrast with other studies like Malissiova et al., 2015 (6.7 X $\left.10^{3} \log \mathrm{cfu} / \mathrm{ml}\right)$; Sarno et al., 2012 (less than $4 \log \mathrm{cfu} / \mathrm{ml}$ ); Count ranging from 4 to $4.7 \log \mathrm{cfu} / \mathrm{ml}$ (Chiavarin et al., 2005, Zhang et al., 2008, Ivankovi et al., 2009, Addo and Ferragut 2015, Salimei et al., 2004, Coppola et al.,2002, Sorrentino et al., 2010) and Cavallarin et al., 2015 (5 log cfu/ml) (Table 1).

All samples were negative for moulds/yeast and also for pathogens like $S$. aureus, Salmonella spp., E. coli, Bacillus cereus, lactose fermenters / non fermenters and
Streptococcus spp. Our study revealed the absence of pathogens in raw DM, similar studies conducted earlier also revealed the same results with the exception of some studies which showed the presence of $S$. aureus (Pilla et al., 2010) and B. cereus (Cavallarin et al., $2015-1.3 \times 10^{2} \mathrm{cfu} / \mathrm{mL}$, Bartoszewicz, et al., 2008, Scatassa et al., 2011) in raw DM samples.

The number of viable cells of the tested $S$. aureus decreased significantly in artificially contaminated DM (Table 2) in comparison with positive controls after one $\mathrm{hr}$ and five hours of incubation. In samples $3 \& 4$ the bacterial count reduced below the detection limit of $<1 \log \mathrm{cfu} / \mathrm{ml}$ after $5 \mathrm{hr}$ of incubation which indicates the antimicrobial effects of DM. Similar kind of study was carried by Saric et al., (2014) in which they showed the antimicrobial effect of DM against $S$. aureus, Listeria monocytogenes and E. coli. Nazzaro et al., (2010) and Tidona et al., (2011) reported the antibacterial activity of DM toward S. aureus and L. monocytogenes, respectively.

Table.1 Chemical and biochemical analyses of donkey milk samples

\begin{tabular}{|c|c|c|c|c|c|c|c|c|}
\hline $\begin{array}{c}\text { Sample } \\
\text { No. }\end{array}$ & FAT & SNF & $\begin{array}{c}\text { CLR } \\
(\text { Cholesterol) }\end{array}$ & $\mathbf{H}_{2} \mathbf{0}$ & Temperature & $\begin{array}{c}\text { PTN } \\
\text { (Protein) }\end{array}$ & $\begin{array}{c}\text { LCT } \\
\text { (Lactose) }\end{array}$ & $\begin{array}{c}\text { SLT } \\
\text { (Salt) }\end{array}$ \\
\hline $\mathbf{1}$ & 0.66 & 8.63 & 32.4 & 00 & 30 & 3.16 & 4.74 & 0.71 \\
\hline $\mathbf{2}$ & 0.70 & 7.06 & 26.8 & 00 & 31 & 2.59 & 3.88 & 0.58 \\
\hline $\mathbf{3}$ & 0.69 & 7.15 & 27.2 & 00 & 31 & 2.62 & 3.93 & 0.59 \\
\hline $\mathbf{4}$ & 0.59 & 8.49 & 31.9 & 00 & 31 & 3.11 & 4.67 & 0.70 \\
\hline $\mathbf{5}$ & 0.65 & 8.53 & 32.0 & 00 & 29 & 3.13 & 4.69 & 0.70 \\
\hline $\mathbf{6}$ & 0.74 & 8.49 & 32.5 & 00 & 33 & 3.11 & 4.67 & 0.70 \\
\hline
\end{tabular}

Table.2 Enumeration of $S$. aureus in spiked DM samples at different duration of incubations

\begin{tabular}{|c|c|c|c|}
\hline Sample No. & 0 hr (cfus) & 1hr (cfus) & 5hr (cfus) \\
\hline 1 & 263 & 76 & 16 \\
\hline 2 & $>300$ & 97 & 46 \\
\hline 3 & 232 & 54 & 05 \\
\hline 4 & 253 & 59 & 02 \\
\hline 5 & 248 & 64 & 13 \\
\hline 6 & 223 & 39 & 08 \\
\hline
\end{tabular}


This reduction in bacterial count in artificially contaminated DM was mainly attributed to lysozyme which is present in high concentration and therefore it is responsible for antibacterial effect of DM (Coppola et al., 2002; Vincenzetti et al., 2008; Zhang et al., 2008; Tidona et al., 2011; Sarno et al., 2012 and Saric et al., 2014). Lysozyme exhibits antibacterial effect particularly towards gram positive bacteria by cleaving the linkages between $\mathrm{N}$-acetylmuramic acid and 2acetylamino-2-deoxy-D-glucose residues in cell wall (Floris et al., 2003; Van Herreweghe and Michiel, 2012). The lysozyme acitivity against the gram negative bacteria is less sensitive compared to gram positive bacteria may be due to strong barrier of LPS for the penetration of lysozyme to the action sites of gram negative cell wall (Floris et al., 2003). Inspite of this speculation, there are studies which reported the antimicrobial effect of DM against gram negative bacteria like E. coli, Salmonella and other Enterobacteriaceae (Zhang et al., 2008; Tidona et al., 2011; Saric, et al., 2012; Saric, et al., 2014). This indicates the presence of some other factors in DM that also exhibit antimicrobial effect along with lysozyme. Lactoferrin is designated as secondary antimicrobial factor in DM, since it is present in significantly lower concentration in DM in comparison to lysozyme (Coppola et al., 2002; Tidona et al., 2011; Vincenzetti et al., 2008; Zhang et al., 2008).

Negative controls did not reveal any growth of $S$. aureus at different periods of incubation. In disc diffusion test there was a clear zone of inhibition surrounding the whatman filter paper discs which further indicates the antimicrobial effect of DM. A significant antimicrobial effect was exhibited by DM against $S$. aureus in artificially contaminated milk as well as in disc diffusion test. Based on the results obtained in this study we conclude that DM is healthy and exhibits antibacterial effect against $S$. aureus.

\section{Acknowledgment}

Authors are very thankful to the Dean, Veterinary College, Hassan and KVAFSU, Bidar for funding to carry this work. Thanks to Dr. Ravikumar P, Assistant Professor, Department of Veterinary Pathology, Veterinary College, Hassan for providing Milk analyzer to carry this work.

\section{References}

Addo, C.N.A. and Ferragut, V. 2015. Evaluating the Ultra-High Pressure Homogenization (UHPH) and Pasteurization effects on the quality and shelf life of donkey milk. Int. J. Food Stud. 4: 104-115.

Bartoszewicz, M., Hansen, B.M. and Swiecicka, I. 2008. The members of the Bacillus cereus group are commonly present contaminants of fresh and heattreated milk. Food Microbiol. 25(4): 588-596.

Brumini, D., Furlund, C.B., Comi, I., Devold, T.G., Marletta, D., Vegarud, G.E. and Jonassen, C.M. 2013. Antiviral activity of donkey milk protein fractions on echovirus type 5. Int. Dairy J. 28: 109111.

Cavallarin, L., Giribaldi, M., Soto-Del Rio, M.D., Valle, E., Barbarino, G., Gennero, M.S. and Civera, T. 2015. A survey on the milk chemical and microbiological quality in dairy donkey farms located in North Western Italy. Food Control 50: 230-235.

Chiavari, C., Coloretti, F., Nanni, M., Sorrentino, E. and Grazia, L. 2005. Use of donkey's milk for a fermented beverage with lactobacilli. Le Lait 85(6): 481-490.

Coppola, R., Salimei, E., Succi, M., Sorrentino, E., Nanni, M. and Ranieri, P. 2002. Behaviour of Lactobacillus 
rhamnosus strains in ass's milk. Annals Microbiol. 52: 55-60.

Floris, R., Recio, I., Berkhout, B. and Visser, S. 2003. Antibacterial and antiviral effects of milk proteins and derivatives thereof. J. Curr. Pharm. Des. 9: 12571275 .

Iacono, G., Carroccio, A., Cavataio, F., Montalto, G., Soresi, M. and Balsamo, V. 1992. Use of ass'milk in multiple food allergy. J. Pediatr. Gastroenterol. Nutr. 14(2): 177-181.

Ivankovi, C.A., Ramljak, J., Stulina, I., Antunac, N., Basic, I., Kelava, N. and Konjacic, M. 2009. Characteristics of the lactation, chemical composition and milk hygiene quality of the littoraldinaric ass. Mljekarstvo 59(2): 107-113.

Malissiova, E., Arsenos, G., Papademas, P., Fletouris, D., Manouras, A., Aspri, M. Nikolopoulou, A., Giannopoulou, A. and Arvanitoyannis, I.S. 2015. Assessment of donkey milk chemical, microbiological and sensory attributes in Greece and Cyprus. Int. J. Dairy Technol. 68: 1-4.

Mansueto, P., Iacono, G., Taormina, G., Seidita, A., D'Alcamo, A. and Adragna, F. 2013. Ass's milk in allergy to cow's milk protein: a Review. Acta Med. Medit. 29(2): 153-160.

Mao, X., Gu, J., Sun, Y., Xu, S., Zhang, X., Yang, H. and Ren, F. 2009. Antiproliferative and anti-tumour effect of active components in donkey milk on A549 human lung cancer cells. Int. Dairy J. 19: 703-708.

Monti, G., Bertino, E., Muratore, M.C., Coscia, A., Cresi, F. and Silvestro, L. 2007. Efficacy of donkey's milk in treating highly problematic cow's milk allergic children: an in vivo and in vitro study. J. Pediatr. Allergy Immunol. 18: 258-264.

Monti, G., Viola, S., Baro, C., Cresi, F., Tovo, P.A. and Moro, G. 2012. Tolerability of donkey's milk in 92 highly-problematic cow's milk allergic children. J. Biol. Regul. Homeost. Agents 26(3): 75-82.

Nazzaro, F., Orlando, P., Fratianni, F. and Coppola, R. 2010. Isolation of Components with Antimicrobial Property from the Donkey Milk: A Preliminary Study. The Open Food Sci. J. 4: 43-47.

Pilla, R., Dapra, V., Zecconi, A. and Piccini, R. 2010. Hygienic and health of donkey milk during a follow up study. J. Dairy Res. 77: 392-397.

Salimei, E., Fantuz, F., Coppola, R., Chiofalo, B., Polidori, P. and Varisco, G. 2004. Composition and characteristics of ass's milk. Animal Res. 53: 67-78.

Saric, C.L.J., Saric, M.B., Mandic, I.A., Torbica, M.A., Tomic, M.J., Cvetkovic, D.D. and Okanovic, G.D. 2012. Antibacterial properties of Domestic Balkan donkeys' milk. Int. Dairy J. 25: 142-146.

Saric, L.C., Saric, B.M., Mandic, A.I., Kevresan, Z.S., Ikonic, B.B., Kravic, S.Z. and Jambrec, D.J. 2014. Role of calcium content in antibacterial activity of donkeys' milk toward E. coli. Eur Food Res Technol. 239(6): 1031-1039.

Sarno, E., Santoro, A.M.L., Di Palo, R. and Costanzo, N. 2012. Microbiological quality of raw donkey milk from Campania Region. Italian J. Animal Sci. 11: 266-269.

Scatassa, M.L., Carrozzo, A., Ducato, B., Giosue, C., Miraglia, V. and Arcuri, L. 2011. Bacillus cereus isolation in jennet milk. Italian J. Food Saf. 1: 243-246.

Sorrentino, E., Salimei, E., Succi, M., Gammariello, D., Di Criscio, T., Panli, G. and Coppola, R. 2005. Heat treatment of ass's milk, a hypoallergenic food for infancy. Technological innovation and enhancement of marginal products, 569-574. 
Tafaro, A., Magrone, T., Jirillo, F., Martemucci, G., D'Alessandro, A.G., Amati, L. and Jirillo, E. 2007. Immunological properties of donkey's milk: its potential use in the prevention of atherosclerosis. Curr. Pharm. Des. 13: 3711-3717.

Tidona, F., Sekse, C., Criscione, A., Jacobsen, M., Bordonaro, S., Marletta, D. and Vegarud, G.E. 2011. Antimicrobial effect of donkeys' milk digested in vitro with human gastrointestinal enzymes. Int. Dairy J. 21(3): 158-165.

Van Herreweghe, J.M. and Michiel, C.W. 2012. Invertebrate lysozymes: diversity and distribution, molecular mechanism and in vivo function. J. Biosci. 37: 327348.
Vincenzetti, S., Polidori, P., Mariani, P., Cammertoni, N., Fantuz, F. and Vita, A. 2008. Donkey's milk protein fractions characterization. Food Chem. 106: 640649.

Vincenzetti, S., Savini, M., Cecchini, C., Micozzi, D., Carpi, F., Vita, A. and Polidori, P. 2011. Effects of lyophilization and use of probiotics on donkey's milk nutritional characteristics. Int. J. Food Eng. 7(5).

Zhang, X.Y., Zhao, L., Jiang, L., Dong, M.L. and Ren, F.Z. 2008. The antimicrobial activity of donkey milk and its microbial changes during storage. Food Control 19(12): 1191-1195.

\section{How to cite this article:}

Chandrashekar, K.M., R. Sharada and Isloor, S. 2018. Microbial Profile and Antimicrobial Effect of Donkey Milk against Staphylococcus aureus. Int.J.Curr.Microbiol.App.Sci. 7(03): 3237-3242. doi: https://doi.org/10.20546/ijcmas.2018.703.374 